\title{
CRTICA O BOŽIĆU VJENCESLAVA NOVAKA ILI KAKO ISTINSKE LJUDSKE VRIJEDNOSTI PREVLADAVAJU TMINU REALIZMA
}

Diana Njegovan

Poljička cesta 9

HR 21000 Split

diana.njegovan@unifr.ch
UDK: 821.163.42.09Novak,V.

Pregledni članak

Ur.: 2020-5-4

U radu je analizirana Crtica o Božiću Vjenceslava Novaka, s posebnim naglaskom na autobiografske i autoreferencijalne elemente, svjetonazor autora te ton djela. Crtica $o$ Božiću unatoč svojoj kratkoći obiluje sadržajem. Djelo pruža nadu, vjeru u bolji, viši svijet. Ljubav prema obitelji u djelu ublažila je realnost neimaštine siromašnoga profesora i pisca koji s nelagodom iščekuje dolazak Božića jer ne može priuštiti darove svojoj mnogobrojnoj obitelji. Zanimljiva je i katolička inspiracija koja pruža optimizam u uobičajeno tamnom tonu realizma, predstavljenom kroz oskudicu i neimaštinu te zapostavljenost intelektualca koji obitava na socijalnoj periferiji.

U našoj književnosti realizma Novak zauzima značajno mjesto, unatoč tome što njegov opus nije do kraja popisan i istražen. Upravo Crtica o Božiću oslikava autobiografske i autoreferencijalne elemente pisca koji stvara iz potrebe. Proživljenost opisanoga stvorila je zanimljiv doprinos hrvatskog Balzaca, onoga koji je vjerno prikazivao siromahe na rubu egzistencije, uspjevši periferiju smjestiti u središte pozornosti onih koji čitaju te onih koji analiziraju i tumače njegovo stvaralaštvo.

Ključne riječi: realizam, Novak, novela, autoreferencijalnost, svjetonazor

\section{Uvod}

Novela Crtica o Božiću Vjenceslava Novaka prvi je put objavljena 1899. Unatoč svojoj kratkoći, obiluje sadržajima i potiče na promišljanje. Otvara niz zanimljivih pitanja, poput odnosa sredine prema književniku, stvaralaštvu umjetnika, autobiografskih $\mathrm{i}$ autoreferencijalnih elemenata te odnosa prema vjeri i Bogu. Upravo posljednje pitanje otkriva svjetonazor autora te omogućava analizu tona samoga djela. 


\section{Vjenceslav Novak i dosadašnja istraživanja autorova stvaralaštva}

Spomenuto je kako novela Crtica o Božiću Vjenceslava Novaka sadrži autobiografske i autoreferencijalne elemente, stoga će se u ovom dijelu rada prikazati biografija pisca te dosadašnja analiza njegova stvaralaštva, kao i njegov značaj za hrvatsku književnost.

Vjenceslav Novak rođen je 1859. godine u Senju. Po svršetku Učiteljske škole u Zagrebu, pet je godina službovao kao pučki učitelj u Senju. Vlada ga je kasnije poslala u Prag na konzervatorij. Tamo je proveo tri godine. Po povratku je bio profesor u Zagrebu u Učiteljskoj školi, gdje je predavao teoriju i povijest glazbe. Uz to, svirao je orgulje i skladao. Profesorskim pozivom bavio se do smrti 1905. godine. ${ }^{1}$ Vjenceslav Novak prve je radove slao u književne časopise iz Praga ${ }^{2}$, a prva mu je knjiga tiskana 1888. godine, nakon povratka u Hrvatsku .

Slobodan Prosperov Novak navodi kako se Vjenceslav Novak upravo po povratku u Hrvatsku u potpunosti uključio u hrvatski književni život. ${ }^{4}$ Dubravko Jelčić i Vladimir Visković navode kako je Vjenceslav Novak pisac koji je dugo bio zapostavljen od strane književne kritike ${ }^{5}$ iako njegova djela ocrtavaju "naš nacionalni socijalni život na prijelazu stoljeća." ${ }^{6}$ Uzrok zapostavljenosti Novaka treba tražiti u praksi kritičara koji su različita djela proglašavali najboljim Novakovim ostvarajima, što spomenuti autori smatraju dokazom veličine Novaka. ${ }^{7}$ Antun Barac smatra kako su nepovoljne kritike uzrokovane pisanjem o Novakovu opusu na temelju manjeg dijela njegova stvaralaštva, onome objavljenome u izdanjima Matice hrvatske gdje, smatra autor, Novakova osobnost nije došla do izražaja u svojoj punini. Pri tome je velik dio Novakova rada ostajao neistražen. ${ }^{8}$ Nadalje, Jelčić i Visković navode kako Novakovo književno i muzikološko stvaralaštvo još nije istraženo te

${ }^{1}$ A. SEKULIĆ, 1957, 49; D. JELČIĆ - V. VISKOVIĆ, 1996, 9.; I. FRANGES̆ - V. ŽMEGAČ, 1998, 115.; M. JURKOVIĆ, 1996, 78-79.; S. PROSPEROV NOVAK, 2004, 130.; V. BREŠIĆ, 1997, 314.; B. LIVADIĆ, 1925, III-IV.

${ }^{2}$ O ocjeni tih radova vidi M. ŚICEL, 2005, 201. Antun Barac je zapisao kako je Novak bio najplodniji suradnik tadašnjih časopisa. (A. BARAC, 1964, 221) O počecima stvaralaštva te utjecaju Šenoe vidi A. BARAC, 1964, 225-226.; K. NEMEC, 1994, 142.; D. JELČIĆ - V. VISKOVIĆ, 1996, 7, 34.; M. ŠICEL, 2005, 5, 20, 200, 201, 234.; J. VOJVODIĆ, 2008, 419.

${ }^{3}$ D. JELČIĆ - V. VISKOVIĆ, 1996, 9.

${ }^{4}$ S. PROSPEROV NOVAK, 2004, 130.

${ }^{5}$ Vidi i A. BARAC, 1964, 221-224.; A. SEKULIĆ, 1957, 48-51.; M. ŠICEL, 2005, 103.

${ }^{6}$ D. JELČIĆ - V. VISKOVIĆ, 1996, 11.

${ }^{7}$ D. JELČIĆ - V. VISKOVIĆ, 1996, 34-35.

${ }^{8}$ A. BARAC, 1964, 223. 
smatraju kako je Novak, uz Gjalskoga, "najplodniji" te uz Josipa Kozarca "najrealističniji, stilski najčistiji te najhomogeniji pisac hrvatskog realizma". ${ }^{9}$ Miran je Jurković zapisao kako je Novak pisao brzo, uvrštavajući istodobno "bitno i nebitno, značajno i beznačajno". Uzrok tome traži u Novakovu osjećaju kako mu nije dano vremena. Jurković navodi kako je Novak gotovo uvijek pisao u sadašnjosti i o suvremenim temama te kako nije stvorio "velike likove", no ipak, uspio je osigurati sebi značajno mjesto u hrvatskoj književnosti. ${ }^{10}$ Barac zamjera Novaku što je svojoj "riznici dragocjenih motiva" pristupao podjednako, ne idući u dubinu i ne postigavši traženi umjetnički učinak. ${ }^{11}$ Livadić i Barac pri ocjeni Novakova opusa daju prednost iznimnoj darovitosti opažanja nad književnim umijećem. Uzrok tome treba tražiti u njegovoj borbi za egzistenciju koja ga je poticala na pisanje, stoga on, uz dobra djela, ima i ona površna ${ }^{12}$. Međutim, Livadić ističe kako je u to vrijeme Novak bio najracionalniji realist te da ima značajno mjesto u hrvatskoj književnosti ${ }^{13}$ kada se prouči njegov opus u cjelovitosti. ${ }^{14} \mathrm{U}$ Novakovu se radu vidio razvoj i usavršavanje. ${ }^{15}$ Pisao je lako, ali je bio "žrtva brzine". ${ }^{16}$ Livadić je primijetio tri faze Novakova prikazivanja bijede. Prva je kada prikazuje bijedu, druga kada traži uzroke zla, a treća je iznošenje vlastita svjetonazora kao rješenja problema. ${ }^{17}$

Analizirajući Novakovo stvaralaštvo, Ivo Frangeš i Viktor Žmegač navode kako on spada među pisce zahvaljujući kojima je novela poprimila novo značenje, približivši se psihologiji. No, te promjene nisu vidljive isključivo na noveli, već je promjene doživio i roman - počeo se baviti društvenim temama. ${ }^{18}$ Socijalne su i psihološke teme bile bliske Novaku, budući da mnogi autori navode kako Vjenceslav Novak spada među autore koji su živjeli teško, u bijedi, žrtvujući se za svoj rad te koji su često pobolijevali. ${ }^{19}$

${ }^{9}$ D. JELČIĆ - V. VISKOVIĆ, 1996, 7, 9, 10, 36.

${ }^{10}$ M. JURKOVIĆ, 1996, 78, 84-85, 88.

${ }^{11}$ A. BARAC, 1964, 235. Sekulić se poziva na navode Barca o navedenome, kao i o izostanku stvaranja velikih likova hrvatske književnosti. (A. SEKULIĆ, 1957, 55)

12 A. BARAC, 1964, 231-235, 238, 240-242, 146-250.; B. LIVADIĆ, 1925, IX-X, XXIV-XXV.

${ }^{13}$ Vidi B. LIVADIĆ, 1925, X, XXII.

${ }^{14}$ B. LIVADIĆ, 1925, X, XXIX.

${ }^{15}$ A. BARAC, 1964, 239-240.; B. LIVADIĆ, 1925, XXIV-XXV.

${ }^{16}$ S. PROSPEROV NOVAK, 2004, 131.

${ }^{17}$ B. LIVADIĆ, 1925, XXVII.

${ }^{18}$ I. FRANGEŠ - V. ŽMEGAČ, 1998, 23.

${ }^{19}$ Ibid., 115.; I. MANDIĆ HEKMAN, 2011, 83.; B. LIVADIĆ, 1925, IV-IX. 
Krešimir Nemec primijetio je kako je Novak prvi u hrvatskoj književnosti svojim djelima usmjerio pozornost na socijalnu tematiku. ${ }^{20}$ Socijalna tematika popraćena je osjećajnosti te je obuhvatila širok motivski raspon. ${ }^{21}$ Vlatko Pavletić, uz sućut prema potlačenima, primijetio je izostanak osude u djelima Vjenceslava Novaka, s obzirom na činjenicu kako mu je o pisanju ovisila egzistencija. ${ }^{22}$ Navedeno je kasnije istaknuo i Slobodan Prosperov Novak. ${ }^{23}$ S druge strane, Ivana Mandić Hekman navodi kako su neka djela Vjenceslava Novaka i Josipa Kozarca bila izmijenjena po zahtjevima nakladnika jer su iznosila "preslobodne scene ili kritike". ${ }^{24}$ Antun je Barac spomenuo ovisnost egzistencije Vjenceslava Novaka i obitelji o književnom stvaralaštvu senjskoga pisca, ali i podatak kako tada u Hrvatskoj nije bio moguć potpuno slobodan književni rad"nastojeći udovoljiti širokom krugu čitatelja. ${ }^{25}$ Barac je također primijetio kako je borba za egzistenciju te privređivanje pisanjem prikazano $\mathrm{u}$ Crtici u Božiću. ${ }^{26}$

U ocjeni Novakova stvaralaštva većina autora se slaže kako je on predstavnik hrvatskoga realizma. ${ }^{27} \mathrm{Uz}$ to, jedan je od najplodnijih pisaca razdoblja. ${ }^{28} \mathrm{Uz}$ obilnost Novakova stvaralaštva, Antun Barac i Draga Ungaro smatraju kako je Vjenceslav Novak "jedan od najinteresantnijih autora." ${ }^{29}$ Barac napominje kako je brojnost Novakovih radova značajna posebice ako se uzme u obzir činjenica kako je senjski pisac najveći dio svoga vremena posvećivao profesorskom pozivu. ${ }^{30} \mathrm{Uz}$ to, navodi kako je iznio nenadmašivo obilje likova, bez šablonskih sličnosti, kako je najdublje oslikao slojeve hrvatskoga društva te kako je u onim djelima kada je pisao bez prilagođavanja čitateljstvu ostvario veliku književnu vrijednost. Iako je broj takvih djela manji, ona su mu osigurala

${ }^{20}$ K. NEMEC, 2010, 146.

${ }^{21}$ A. SEKULIĆ, 1957, 14, 48.; J. VOJVODIĆ, 2008, 420.

${ }^{22}$ V. PAVLETIĆ, 1956, 119.

${ }^{23}$ S. PROSPEROV NOVAK, 2004, 130.

${ }^{24}$ I. MANDIĆ HEKMAN, 2011, 85.

${ }^{25}$ A. BARAC, 1954, 238-239, 242.

${ }^{26}$ Ibid., 239.

${ }^{27}$ A. SEKULIĆ, 1957, 50, 56.; D. JELČIĆ - V. VISKOVIĆ, 1996, 34-36.; D. UNGARO, 1997, 198.; J. VOJVODIĆ, 2008, 420-421.; K. NEMEC, 1994, 135, 145.; M. JURKOVIĆ, 1996, 84.; M. ŠICEL, 2005, 5, 20, 72.; S. ČULJAT, 2012, 10, 215. Krešimir Nemec navodi kako su najznačajnija Novakova djela nastala u doba moderne (K. NEMEC, 1998, 13). O Novaku kao autoru djela zakašnjeloga realizma govori i Miroslav Šicel. (M. ŠICEL, 2005, 76)

${ }^{28}$ A. SEKULIĆ, 1957, 48-49, 55-56.; J. MATEŠIĆ, 1991, 81; J. VOJVODIĆ, 2008, 420.

${ }^{29}$ A. BARAC, 1964, 220; D. UNGARO, 1997, 198.

${ }^{30}$ A. BARAC, 1964, 221. 
mjesto među značajnim piscima hrvatskoga realizma. ${ }^{31}$ Ungaro navodi kako je hrvatska književna kritika ocijenila Novaka kao "kritičara malograđanstva te pjesnika sirotinje". ${ }^{32}$ Opis Novaka kao čovjeka koji je vodio "nemilosrdnu borbu sa životom", osobe koja je toplo slikala sudbine patnika, pridobivši naklonost čitatelja načinio je Ante Sekulić. ${ }^{33}$ Dragomir Babić navodi kako je Novak "najsenjskiji pisac", poznat kao i hrvatski Balzac. Posljednji je opis stekao zahvaljujući Ivi Frangešu. ${ }^{34}$

Sintija Čuljat navodi kako Frangeš Novaka smatra jednim od najplodnijih te najraznovrsnijih pisaca hrvatskoga realizma. ${ }^{35}$ Novak je, smatra kritika, obuhvatio sve društvene slojeve i pojave pred kraj 19. stoljeća. Njegov opus dijele na: prikaz Senja, prikaz senjske okolice i Podgorja, prikaz hrvatskoga kulturnoga i socijalnog života te svijet sirotinje, uz prve pojave socijalizma. ${ }^{36}$ Miroslav Šicel u Novakovu je opusu uočio motive rodnoga Senja, iznimnu sposobnost zapažanja, osjetljivost na socijalne teme i proživljenost istih te prevlast pojedinačnih sudbina u njegovim djelima. ${ }^{37}$ Stjepan Vukušić smatra kako je značaj Vjenceslava Novaka u hrvatskoj književnosti neosporan. Njegov značaj je u tome što je u književnost uveo sliku velebitske krajine, vjerno oslikavši njezine prilike. ${ }^{38}$ Vjenceslav je Novak bio "najbolji tumač etike hrvatskog primorskog građanstva. ${ }^{139} \mathrm{~S}$ tim u skladu je komentar Vukušića kada je zapisao kako je Novak umio: "Od siromaštva stvoriti bogatstvo: u siromaštvu otkriti bogatstvo." ${ }^{40}$ Sintija Čuljat je prepoznala tu Novakovu težnju te smatra kako je značaj senjskog pisca upravo u tome što se usredotočio na ono što se nalazilo na rubu, na regionalno i provinciju. Ona se nalazila geografski na rubu Austrijskog Carstva, ali i europske književne politike. Novak je tom prostoru dao važnost oslikavši socijalno i psihološki likove tog područja ${ }^{41}$ Čuljat je

${ }^{31}$ Ibid., 231-250.

${ }^{32}$ D. UNGARO, 1997, 199.

${ }^{33}$ A. SEKULIĆ, 1957, 48-56.

${ }^{34}$ D. BABIĆ, 1984, 239; M. ŠICEL, 2005, 76.

${ }^{35}$ S. ČULJAT, 2012, 199 prema I. FRANGEŠ, 1960.

${ }^{36}$ A. SEKULIĆ, 1957, 53-55.; A. BARAC, 1964, 226-230. D. BABIĆ, 1984, 239. Jelčić i Visković navode kako je Novak među prvim autorima koji je u hrvatsku književnost uveo socijalne i socijalističke teme, no ne kao svoj svjetonazor, već kao književnu temu. (D. JELČIĆ V. VISKOVIĆ, 1996, 35)

${ }^{37}$ M. ŠICEL, 2005, 189, 202, 204.

${ }^{38}$ S. VUKUŠIĆ, 1988, 187.

${ }^{39}$ S. PROSPEROV NOVAK, 2004, 130.

${ }^{40}$ S. VUKUŠIĆ, $1982,477$.

${ }^{41}$ S. ČULJAT, 2012, 10, 215.; S. ČULJAT, 2017, 437-448. 
primijetila kako se krajolik i likovi sjedinjuju preslikavajući si karakteristike. ${ }^{42}$ Nadalje, smatra kako Novak raskida s književnim konvencijama kada projicira treće prostore, odnosno svijet umjetnosti i glazbe. ${ }^{43}$

Zanimljiv je stav Krešimira Nemeca koji naziva Novaka "najvećim eksperimentatorom $\mathrm{i}$ inovatorom od svih naših realista, koji je zainteresiran za psihologiju i sudbinu pojedinca, autora koji je primjenjivao smjela kompozicijska rješenja te se okušao u multiperspektivnu pripovijedanju."44

Navedeni pregled upućuje na zaključak kako Vjenceslav Novak zauzima značajno mjesto u hrvatskoj književnost, ostavši upamćen kao najplodniji pisac hrvatskoga realizma. Prvi je oslikao socijalne teme, stoga je okarakteriziran kao hrvatski Balzac. Budući da je živio od svoga stvaralaštva, pisao je brzo stvorivši veliki broj djela neujednačena dometa. No, velik je dio njegova stvaralaštva ostao neistražen i otvoren analizama.

\section{Analiza Crtice o Božiću}

Novela se odvija dan pred Badnjak. Protagonist je književnik i nastavnik Makso. Ima mnogobrojnu obitelj koju teško uzdržava profesorskom plaćom, stoga također piše za novine. S obzirom na to da se bliži Božić, njegova se djeca raduju darovima Malog Isusa, a on zna da će to biti teško ostvarivo jer u kući nema novaca. Odlučio je stoga ponuditi uredniku svoju crticu o Božiću kako bi predujmom osigurao obitelji najnužnije, no odbijen je. Njegov pjesnički ponos je pogažen, ali zbog obitelji ne odustaje te odlazi k drugom uredniku. No, ni on nema razumijevanja za njega. Konačno, odluči pitati pozajmicu kod trgovca kod kojega njegova žena često kupuje, ali ga i trgovac odbija. Zbog pogažena ponosa ne može pisati. Sumnja u ljubav vlastite žene koja je bolesna od rođenja šestoga djeteta. Tek kada se uvjerio da njegova žena voli svu svoju djecu, uspijeva se radovati rođenju Božjeg Djeteta, slavi i dovršava svoju crticu.

Sadržaj omogućava propitivanje važnosti odnosa sredine prema književniku, što se još jasnije vidi u sljedećim navodima. Na samom početku rečeno je kako protagonist Makso "već davno ništa nije napisao te kako je: "U njegovoj bujnoj i plodnoj inače mašti vladala [je] od nekog vremena pustoš, i pravu, jednu ideju, koja bi se dala umjetnički obraditi, nije mogao uhvatiti. ${ }^{45}$

\footnotetext{
${ }^{42}$ Ibid., 217.

${ }^{43}$ Ibid., 216-217.

${ }^{44}$ S. ČULJAT, 2017, 444 prema K. NEMEC, 1995, 237-238.; K. NEMEC, 1994, 237.

${ }^{45}$ V. NOVAK, 1925, 135.
} 
Katkada bi poradi te svoje nemoći klonuo ogorčen do plača. Ćutio je, da moć stvaranja nije u njegovoj duši umirala; no nije mogao da je razbudi, da se prelije u sav njegov život, da potpuno ovlada njime, pa zaboravi sve drugo toliko, te poslije, kad dobije u ruke napisano, čita kao nešto poznato iz daleka, kao da je bio sretan, kad je poćutio ono stanovito zagrijavanje u duši, s kojim je bilo uspješno raditi."46 Međutim, "prilike, u kojima je radio, nijesu nimalo pogodne radu književnika ${ }^{47} \mathrm{i}$ one su bile glavni neprijatelj njegova umjetničkog stvaranja." 48 Citati oslikavaju borbu umjetnika koju vodi sa samim sobom pri nastajanju književnog djela. Prisutna je i neimaština koja dodatno otežava stvaranje. U oslikavanju njegove situacije prisutna je i ironija kojom je naglasio svoju nesreću i nerazumijevanje na koje je nailazio: "Drže me pjesnikom i misle, da moram rađati za javnu štampu umjetnine kao voćka plodove. $\mathrm{Nu}$ voćku goje, đubre, obrezavaju i omataju zimi slamom - a za mene nema srca baš nitko." ${ }^{49}$ Ovi citati vjerno prikazuju nemoć protagonista, njegovo razočaranje te su zanimljiv doprinos temi odnosa društva prema književniku. Od njega se očekuje da stvara, i to da stvara vrijedna djela, a njegove socijalne prilike ga opterećuju. Bio je prisiljen tražiti pozajmice, a svako odbijanje gazilo mu je ponos. To je vidljivo iz sljedećih navoda: "Njegova pjesnička duša klonula je kao svagda, kad bi mu tko ponos i malo ozlijedio; bilo mu je, kao da ga je zahvatio udarac, od kojega se već ne će nikada podići." 50

O opisu odnosa društva prema književniku prikazanome u ovome djelu Marin Pavlinović je u djelu Studije, eseji, prikazi iz 1930. zapisao kako su oslikane "očajne književne prilike" koje se do tadašnjeg nadnevka, po mišljenju Pavninovića, nisu popravile već znatno pogoršale. ${ }^{5 l}$ Ante Sekulić je zapisao kako Novaka obilježava "tragični raspon umjetnika žednog ljepote i čovjeka kojeg život lomi." 52 Ti su elementi prisutni u Crtici o Božiću, stoga će ovaj rad istražiti vezu između biografskih činjenica Vjenceslava Novaka i njegova protagonista $u$ analiziranome djelu.

Spomenuto je kako Crtica o Božiću oslikava težak život profesora i pisca koji svojom radom pokušava osigurati vlastitu egzistenciju te kako je Novak

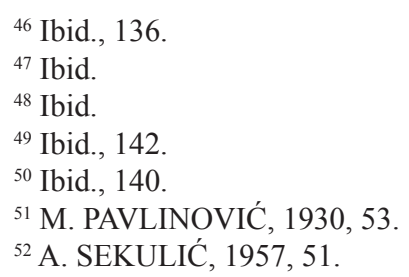


dobro poznavao socijalne probleme jer je i sam iskusio glad. Protagonist navedene novele je profesor, baš kao i Novak. Obojica imaju mnogobrojnu obitelj te su im socijalne prilike jedan od poticaja za pisanje. Psihološki i socijalni elementi izraženi su u analiziranome djelu, a Krešimir je Nemec primijetio kako je "poraz Novakovih junaka redovito rezultanta podjednako naglašenih socijalnih i psiholoških čimbenika." ${ }^{53}$ Draga Ungaro zapisala je kako je Novak u svojoj Crtici o Božiću opisao sebe samoga. U to se uvjerila razgovorom s njegovom djecom. Naime, i sam je Novak pisao noću dok bi njegovo sedmero djece spavalo. Neprekidno je pisao kako bi prehranio brojnu obitelj, čak i kada je obolio jer profesorska plaćanije bila dovoljna. ${ }^{54}$ Ungaro je navela i kako se sam Novak kritički odnosi prema svom stvaralaštvu, te kako, je riječima svoje djece, žalio je što nije imao vremena usavršavati napisana djela. ${ }^{55}$ Novakova se supruga također žrtvovala za obitelj. Umorna od rada noću bi čvrsto spavala. ${ }^{56}$ Ta je slika poslužila u Crtici o Božiću. Barac je pisao kako se u Crtici o Božiću i nekim drugim Novakovom djelima pojavljuje motiv žene koja ne razumije u potpunosti svoga supruga, ali unatoč tome, izvrsno ostvaruje svoju ulogu majčinstva. ${ }^{57}$

Marin Pavlinović, inače nesklon karakterizaciji Novaka kao realista ${ }^{58}$, analizirao je upravo dijelove Crtice o Božiću u kojima Makso proučava vlastitu suprugu te smatra kako je Novak u djelu imao "dosta smisla za detalj", koji u njegovu stvaralaštvu nije bilo u "skladu sa modernim estetskim i psihološkim naziranjima." ${ }^{99}$ Pavlinović također navodi kako je Novak u Crtici o Božiću špontaniji, koncizniji, dublji, ekonomičniji, kojeg ne vodi predmet i fabula, nego vješto on njih". Smatra kako je izgradio protagonista "kao čudaka individualista, filozofa, kojeg svijet ne razumije, pak radi toga postaje skeptik prema svemu, pa i ljubavi svoje žene." ${ }^{10}$ Josip Badalić pisao je o Novakovu svjetonazoru, budući

${ }^{53}$ D. DURIĆ, 2011, 21 prema K. NEMEC, 1999, 227.

${ }^{54}$ D. UNGARO, 1997, 195-198.

${ }^{55}$ Ibid., 196-198.

${ }^{56}$ Ibid., 195-197.

${ }^{57}$ A. BARAC, 1864, 245.

${ }^{58}$ Vidi M. PAVLINOVIĆ, 1930, 5, 45, 46, 61, 62. Pavlinović se ne slaže ni s ocjenom kako je Novak "senjski Šenoa". (M. PAVLINOVIĆ, 1930, 49) Pavlinović smatra kako je Novak predstavnik hrvatskoga feuilleton-romana, dobar poznavatelj ličke i senjske sirotinje $i$ osoba osrednjih duševnih sposobnosti. Smatra kako je Novak pozitivna pojava koja je znala dotaknuti srca čitatelja. Navodi kako je njegovo djelovanje i pisanje djelo srca i osjećaja. (M. PAVLINOVIĆ, 1930, 62)

${ }^{59}$ M. PAVLINOVIĆ, 1930, 54.

${ }^{60}$ Ibid., 52. 
da Novak spada među pisce koje iznimno zanimaju problemi o svijetu i životu. Smatrao je kako se kod Novaka može uočiti postojanje dvaju svjetonazora. U prvom razdoblju do 1900. godine prevladava kršćanstvo, dok u posljednjoj fazi prevladava panteističko-spirističko uvjerenje. Istaknuo je kako ova podjela nije oštra jer Novak nije uvijek dosljedan, što je posljedica njegova neumorna stvaranja i izostanka formalnog filozofskog obrazovanja. Uz to, navodi kako je Novak i odgojen u kršćanskom duhu te je kao orguljaš bio povezan s crkvenim krugovima te je zbog egzistencije bio na oprezu o sadržajima koje piše, ali, smatra Badalić, duh kršćanstva ga nije dublje prožeo. Navodi također kako Novak nikada nije bio materijalist te kako su materijalne prilike uzrok zla. ${ }^{61}$ Protagonist Crtice o Božiću smatra kako su najveća poezija upravo djeca te čini sve zbog njih smatrajući ih svojim najvećim blagoslovom: "poradi svoje djece. Poradi njih, samo poradi njihove budućnosti osjećao je već davno vrijednost svog života. No pa nijesu li djeca, taj biljeg vječnog preporađanja svijeta, živa i najnosnija poezija, nosioci ideja, što će ispunjavati budućnost? ${ }^{62}$ Zapisano je: Što vrijedi brak bez djece - bez blagoslova?"63 Već sama riječ blagoslov, potiče na raspravu o odnosu prema Bogu koji ova novela pruža. No, u prilog opterećenosti protagonista novčanim pitanjem ide ovaj citat: "U to nije vjerovao, da ima pravo svojom grubom pojavom zaći u carstvo, gdje vlada duh, apsolutna ideja. To materijalno i novčano pitanje, neprekidna gotovo, a odurna briga, kako će namaknuti obitelji, što treba za život." ${ }^{64}$ Ipak, ideja o postojanju boljeg, višeg svijeta prevladava te prilike: "Osjećao je da, istodobce s grubim materijalnim svijetom postoji viši, bolji i neusporedivo ljepši svijet duha, svijet ljubavi, svijet ideja... da jest, da mora biti sjajno carstvo konačne sreće, u koju može zagledati svojom intuitivnom snagom samo duh velikih, rijetkih ljudi, umjetnika i pjesnika, koji to carstvo navještavaju u svojim djelima bijednicima na utjehu, kao što su proroci staroga svijeta navještavali dolazak Spasa."65 Navedeni citati potkrepljuju Badalićev stav kako Novak nije materijalist te kako vjeruje u postojanje dvaju svjetova: materijalnog i onog višeg. ${ }^{66} \mathrm{Za} \mathrm{uočiti}$ je kako je spomenut duh, apsolutna ideja bez isticanja Boga, no ona je vezana uz stvaralačku energiju pjesnika. Na samom kraju novele, kada je protagonist uspio prevladati tminu svoje egzistencije i usredotočiti se na dobrotu u svijetu,

\footnotetext{
${ }^{61}$ J. BADALIĆ, 1935, 307-311.

${ }^{62}$ V. NOVAK, 1925, 137.

${ }^{63}$ Ibid.

${ }^{64}$ Ibid.

${ }^{65}$ V. NOVAK, 1925, 150-151.

${ }^{66}$ J. BADALIĆ, 1935, 311-312.
} 
zapisano je: ...."i napokon to obilno i nečujno padanje snijega, što ga je Makso voljko raspoložen u svojoj idealnoj duši isporedio blagoslovu i sreći, kojom Bog u te božićne dane pohodi najbjedniju kršćansku dušu." ${ }^{67}$ Protagonist je proživio kršćanske pjesme: "Narodi se kralj nebeski... Slava Bogu na visini, a mir ljudima dobre volje!"68 Može se primijetiti kako protagonist smatra djecu blagoslovom i darom Božjim. Kada je shvatio da supruga voli i njihovo šesto dijete, unatoč svojoj patnji, poistovjetio je slavlje bogorađanja s vlastitom srećom i blagoslovom. To je pokrenulo njegovo pjesničko, odnosno umjetničko nadahnuće. Iz toga slijedi da je kršćanstvo duboko ukorijenjeno u životu protagonista. No, što je sa svijetom ideja pjesnika te apsolutnim duhom? Kao odgovor na navedeno pitanje može poslužiti sljedeći citat: "U školi su me učili, a i sam kazujem svojim učenicima pripovijesti, koje se kroz stotine i stotine godina preštampavaju iz starih knjiga u nove o izmišljenoj snazi duha nekih ljudi, kojih se nije dojmila ni nesreća, ni nepravda, ni ponizivanje, ni oskudica, niti ikakvo trpljenje, koji su tobože ostali svagda i u svakoj prilici jednako veliki i uzvišeni nad običnim svijetom, ma baš poput samog Krista. A ne može da čovjek bude kao Bog!"69 Vidljivo je kako je svijet ideja i uzvišeni svijet nadahnuća povezan s vjerom. Također je navedeno kako je protagonista kušao đavolčić u stvaralaštvu i u vjeri u ljubav vlastite žene prema djeci. Nadalje, kada je želio tražiti pomoć, u njemu su se sukobljavala dva čovjeka: "u njem se srela dva čovjeka, dva ljuta neprijatelja, i zakvačila se u borbu na život i smrt."70 Baš poput borbe dviju suprotnosti - dobra i zla. Djelo završava porukom ljubavi, osjećajima sreće zbog djeteta kao dara i blagoslova. Vidljivo je da ovo djelo promiče kršćanske vrijednosti, što i periodizacija Badalića navodi. Za primijetiti je kako prevladavanje kršćanske tendencije postoji do 1900., a novela je objavljena 1899.

Moguće je analizirati i ton koji prevladava u Crtici o Božiću, odnosno propitivanje pretpostavke hoće li u samom djelu prevladati optimizam ili pesimizam. Barac je pisao kako Novak nije posjedovao jedinstven pogled na svijet. Posljedica navedenog je neudjenačenost i nedorečenost Novakova opusa. Uzrok tome traži u izostanku sustavnoga obrazovanja, no priznaje Novaku napredovanje i boljitak koji su ostvareni ponovnom obradom istih tema ${ }^{71}$. Međutim, navodi kako bi se, unatoč postojećim proturječnostima, kao Novakov

${ }^{67}$ V. NOVAK, 1925, 135.

${ }^{68}$ Ibid., 151.

${ }^{69}$ Ibid., 140-141.

${ }^{70}$ V. NOVAK, 1925, 143.

${ }^{71}$ A. BARAC, 1964, 237-249, 242. 
Životni stav mogla uočiti prevlast osjećaja nad razumom..$^{72}$ Šicel navodi kako je Novak "autor neizgrađene i u suštini kontradiktorne filozofije." ${ }^{73}$ Sekulić je u svom djelu o hrvatskome realizmu 1957. zapisao suprotno mišljenje, budući da je Novak težio za znanjem te napredovao. ${ }^{74}$ Livadić kod Novaka uočava "čelični optimizam."75 Badalić smatra kako Novak nije ni tu dosljedan te kako sve ovisi o raspoloženju. Prevladava elegičan ton koji pokatkad Novak ublaži. ${ }^{76} \mathrm{Na}$ početku analizirane novele protagonist je optimističan, pokreće ga njegova zamisao kako će svojim pisanjem omogućiti obitelji najnužnije. Suočava se s okrutnosti svijeta i to unosi tamu, on je potišten, ali zbog djece ne odustaje. Unatoč tome što ga nitko od onih koji bi mu mogli pozajmiti novac ne shvaća, on slavi bogorađanje i raduje se ljubavi kada shvati da njegova žena voli svu njihovu djecu. Stoga, u djelu su prilike opisane realno. Unatoč težini situacije i bijedi zbog socijalne situacije, prevladava optimizam, koji ublažava bijedu i usmjerava pogled na ono više. Može se reći da ovo djelo zbog tog usmjerenja prevladava tminu realizma. U Crtici o Božiću protagonist je realistički oslikan. Oslikana je sudbina pojedinca, književnika i profesora koji je na rubu egzistencije, intelektualca koji životari na periferiji. Tu se očituje Novakova karakteristika slikanja socijalnih i psiholoških motiva.

\section{Zaključak}

U radu je analizirana Crtica o Božiću Vjenceslava Novaka. Zahvaljujući korpusu koje djelo pruža te studijama o Novaku i njegovu stvaralaštvu, promotrene su značajke samog djela, proces nastajanja književnog djela, poteškoće u tom procesu te odnos sredine prema književniku i znanosti prema Novaku samome. Analizirani su i mogući autoreferencijalni elementi, s obzirom na to kako je protagonist pisac i književnik, poput samoga Novaka. Također je analiziran ton koji djelo pruža te odnos prema vjeri i Bogu kao odlike autorova svjetonazora.

Naime, analizirajući Novakov opus može se naići na pitanje kakav uistinu ton prevladava u djelu te što to znači za same protagoniste. Radnja Crtice o Božiću odvija se tijekom jednoga dana. Autor je u potpunoj besparici

${ }^{72}$ Ibid., 245.

${ }^{73}$ S. ČULJAT, 2017, 444 prema M. ŠICEL, 1979, 68.

${ }^{74}$ A. SEKULIĆ, 1957, 19-50.

${ }^{75}$ B. LIVADIĆ, 1925, IX. Pavlinović u analizi Novakova djela prenosi Livadićeve stavove o optimizmu Novaka. (Vidi M. PAVLINOVIĆ, 1930, 47, 48)

${ }^{76}$ J. BADALIĆ, 1935, 315-316. 
i bez inspiracije, a o njemu ovisi mnogobrojna obitelj. Kako bi ispunio svoju očinsku dužnost, gazi ponos i moli za pomoć. Bliži se rok za dostaviti crticu, a on je u crnim mislima. Tek kad shvati kako njegova supruga uistinu voli i njihovo šesto dijete, iako se još uvijek oporavlja od poroda i opterećuje je neimaština, protagonist može slaviti rođenje božanskog djeteta i prevladati pesimizam.

Novak, dugo zanemarivani autor, čiji opus ni do danas nije do kraja istražen, ubraja se među najplodnije pisce hrvatskoga realizma. Vjerno je oslikao borbu za egzistenciju svoga protagonista, intelektualca koji živi na rubu egzistencije, koji predstavlja primjer Novakova realistična oslikavanja društva, u čemu je ostvario prvenstvo među piscima hrvatske književnosti. U djelu su prisutni autobiografski i autoreferencijalni elementi s obzirom na podudarnost protagonista i Novakova života. Obojica su se jedva izdržali profesorskom plaćom te su pisali kako bi prehranili mnogobrojnu obitelj. Međutim, uz sve je nedaće prisutan pozitivan ton, kao posljedica prisutnosti kršćanskih elemenata te jakog autorova optimizma. Upravo kontekst bogorađanja te ljubavi prema obitelji daju svježinu i ublažavaju surovost realizma, ukazujući na važnost općeljudskih vrijednosti koje nadilaze patnju. Ova odlika čini djelo zanimljivim doprinosom Vjenceslava Novaka, hrvatskoga Balzaca, koji je neumorno stvarao.

Kritika se slaže kako je njegov opus neujednačen, no njegov značaj se i danas otkriva analizom njegova, još u cijelosti nepopisana i neistražena, opusa. Unatoč tome, dodijeljeno mu je značajno mjesto među hrvatskim realistima, a upravo su njegova djela trag stradavanja siromašnih, potlačenih i obespravljenih osoba na periferiji. Novak je tu nekadašnju periferiju pretvorio u središte zanimanja i istraživanja.

\section{Literatura}

\section{Izvor}

Vjenceslav NOVAK, Crtica o Božiću, Izabrane pripovijesti Vjenceslava Novaka. Uredio is uvodom popratio Branimir Livadić. Knjiga 1., Izvanredno izdanje Matice hrvatske Zagreb, 1925, 135-151.

\section{Knjige i članci}

Dragomir BABIĆ, Podgorska dimenzija Vjenceslava Novaka, Senjski zbornik, 10-11, Senj, 1984, 239-245. 
Josip BADALIĆ, Vjenceslav Novak i njegov nazor o svijetu, Obnovljeni život, 16 (7), Zagreb, 1935, 306-316.

Antun BARAC, Rasprave i kritike, Naprijed, Posveta-Svjetlost, Zagreb-BeogradSarajevo, 1964.

Vinko BREŠIĆ, Autobiografije hrvatskih pisaca, AGM, Zagreb, 1997.

Sintija ČULJAT, Poetika prostora: Kovačić, Novak i Hardy, Hrvatsko filološko društvo - Biblioteka Književna smotra, Zagreb, 2012.

Sintija ČULJAT, Podgorje u pripovjednomu modelu Vjenceslava Novaka, Senjski zbornik, 44, Senj, 2017, 437-449.

Dejan DURIĆ, Autoritet i obitelj u romanu Posljednji Stipančići Vjenceslava Novaka, Kroatologija, 2(1), Zagreb, 2011, 19-40.

Ivo FRANGEŠ - Viktor ŽMEGAČ, Hrvatska novela: interpretacije, Školska knjiga, Zagreb, 1998.

Dubravko JELČIĆ - Vladimir VISKOVIĆ, Posljednji Stipančići Vjenceslava Novaka, Pripovijetke Slavka Kolara, Školska knjiga, Zagreb, 1996.

Miran JURKOVIĆ, Ogledi i kritički dnevnik, Nolit, Beograd, 1966.

Branimr LIVADIĆ, Djelo Vjenceslava Novaka, Izabrane pripovijesti Vjenceslava Novaka. Uredio is uvodom popratio Branimir Livadić. Knjiga 1., Izvanredno izdanje Matice hrvatske, Zagreb, 1925, III-XXXIII.

Ivana MANDIĆ HEKMAN, Od bajke do avangarde, Ex libris, Zagreb-Split, 2011.

Josip MATEŠIĆ, Frazeologija romana Pod Nehajem Vjenceslava Novaka, Senjski zbornik, 18, Senj, 1991, 81-90.

Krešimir NEMEC, Povijest hrvatskog romana od početka do kraja 19. Stoljeća, Znanje, Zagreb, 1994.

Krešimir NEMEC, Povijest hrvatskog romana od 1900. do 1945, Znanje, Zagreb, 1998.

Krešimir NEMEC, Čitanje grada: urbano iskustvo u hrvatskoj književnosti, Naklada Ljevak, Zagreb, 2010.

Vlatko PAVLETIĆ, Kako su stvarali književnici, Školska knjiga, Zagreb, 1956.

Marin PAVLINOVIĆ, Studije, eseji, prikazi, Tisak zaklade tiskare Narodnih novina, Zagreb, 1930.

Slobodan PROSPEROV NOVAK, Povijest hrvatske književnosti. Svezak II. Između Pešte, Beča i Beograda, Marjan tisak, Split, 2004.

Ante SEKULIĆ, Hrvatski realizam, Gradska štamparija Subotica, Zagreb, 1957.

Miroslav ŠICEL, Povijest hrvatske književnosti. Knjiga II. Realizam, Naklada Ljevak, Zagreb, 2005.

Draga UNGARO, Sjećanja na slavne Hrvate, Tonimir, Varaždinske toplice, 1997.

Jasmina VOJVODIĆ, Remen i cipela (Novakova pripovijest o Marcelu Remeniću i Gogoljeva kabanica), Komparativna povijest hrvatske književnosti: zbornik radova X. Smjerovi i metodologije komparativnog pristupa hrvatske književnosti, Književni krug, Split, 2008, 419-427. 
Stjepan VUKUŠIĆ, Spomen ploče u svijetu litica, Senjski zbornik, 9, Senj, 1982, 471477.

Stjepan VUKUŠIĆ, Novakova i Barčeva slika Podgorja, Senjski zbornik, 15, Senj, 1988, $185-188$.

\section{CRTICA O BOŽIĆU OF VJENCESLAV NOVAK OR HOW TRUE HUMAN VALUES OVERRULES THE DARKNESS OF REALISM}

\section{Summary}

In the paper, Vjenceslav Novak's Crtica o Božiću (A Sketch of Christmas) is analysed with a special emphasis on the autobiographical and self-referential elements, the author's worldview and the tone that the work offers. Despite its brevity Crtica o Božiću is full of contents. The work offers hope and belief in a better, higher world. Love for one's family in the work softens the reality of the poverty of a poor professor and writer who is uncomfortably awaiting the arrival of Christmas because he cannot afford gifts for his large family.

Also interesting is the Catholic inspiration that provides optimism in the unusually dark tone of realism, represented via shortages and poverty and the neglect of an intellectual who lives on the social periphery. Novak occupies a significant place in our literature of realism, despite the fact that his opus has not been catalogued and researched completely. In fact Crtica o Božiću depicts autobiographical and self-referential elements of the writer who creates out of necessity. The experience of what was described created an interesting contribution by the Croatian Balzac, the one who faithfully portrayed the poor on the edge of existence, managing to place the periphery in the centre of attention of those who read and those who analyse and interpret his creativity.

Keywords: realism, Novak, novella, self-referentiality, worldview 